\title{
An empirical nexus between oil price collapse and economic growth in Sub-Saharan African oil based economies
}

\author{
KEJI Sunday Anderu \\ Department of Economics, Federal University Oye-Ekiti, Nigeria \\ e-mail correspondence: sunday.keji@fuoye.edu.ng
}

\begin{abstract}
The focus of this study, is to empirically investigate the nexus between oil price collapse and economic growth in sub-Saharan Africa oil based economies, specifically from Angola, Nigeria and Sudan between January, 2010 and December, 2015, through panel random effects model (REM): Economic growth rate (GDPR) and independent variables: Oil price (OPR), Exchange rate (EXR), Industrial Output (IND) and Terms of Trade (TOT. REM result showed that there is negative link between oil price collapse and the economic growth in the case of Angola, Nigeria and Sudan, which confirmed the nexus between oil price collapse and economic growth. Post estimation tests such as Hausman and Breusch and Pagan Lagrange Multiplier Test were adopted to empirically show the consistency and efficiency of the model. Interestingly, the two key variables (GDPR and OPR) disclose how unprecedented oil price fall disrupts economic growth of the selected economies. Meanwhile, poor institutional quality in the oil sector coupled with poor fiscal measure among others, further expose these economies to unprecedented external shocks that was characterized by skyrocket exchange rate, hence destabilize growth within the period under review. Therefore, the need for a robust fiscal measure is pertinent in order to sustain economic growth.
\end{abstract}

Keywords: Empirically, Investigate, Economic growth, Nexus, Oil price collapse, Unidirectional, Responsiveness

\section{INTRODUCTION}

Issues revolving round oil price collapse in recent times have generated series of debates among the scholars and policy makers. In spite the extensive previous empirical findings, the nexus between economic growth and oil price remain ambiguous. Some of the studies (e.g. Oriakhi \& Osaze, 2013; Ebaidalla, 2014; Omojolaibi \& Egwaikhide, 2014; Ebele, 2015) emphasize more on a single economy, which is either concentrated on volatility or shocks in oil price in relation to economic growth. However, findings on persistent collapse oil price across sub-sahara African oil producing economies (such as Angola, Nigeria and Sudan) have been generating serious debates from different researchers. Notably, recent experience shows that constant fall in oil price, which represent almost $57 \%$ drop from the preceding price (that is from $\$ 105$ per barrel in 2013 to nearly $\$ 47$ through mid-November 2014) has continued to generate concerns. It is also, worthy to note that the drop in oil price continue to fall on monthly average Brent crude until 2016 to about $65 \%$ below average.

On this note, Husain et al (2015) point out that this drop has zero effects on global economy, while lower oil prices implications are much felt at the country level due to limit pass through syndrome. That is, where real income gains are accrued to the 
oil companies at the expense of end users which is characterized by weak fiscal response.

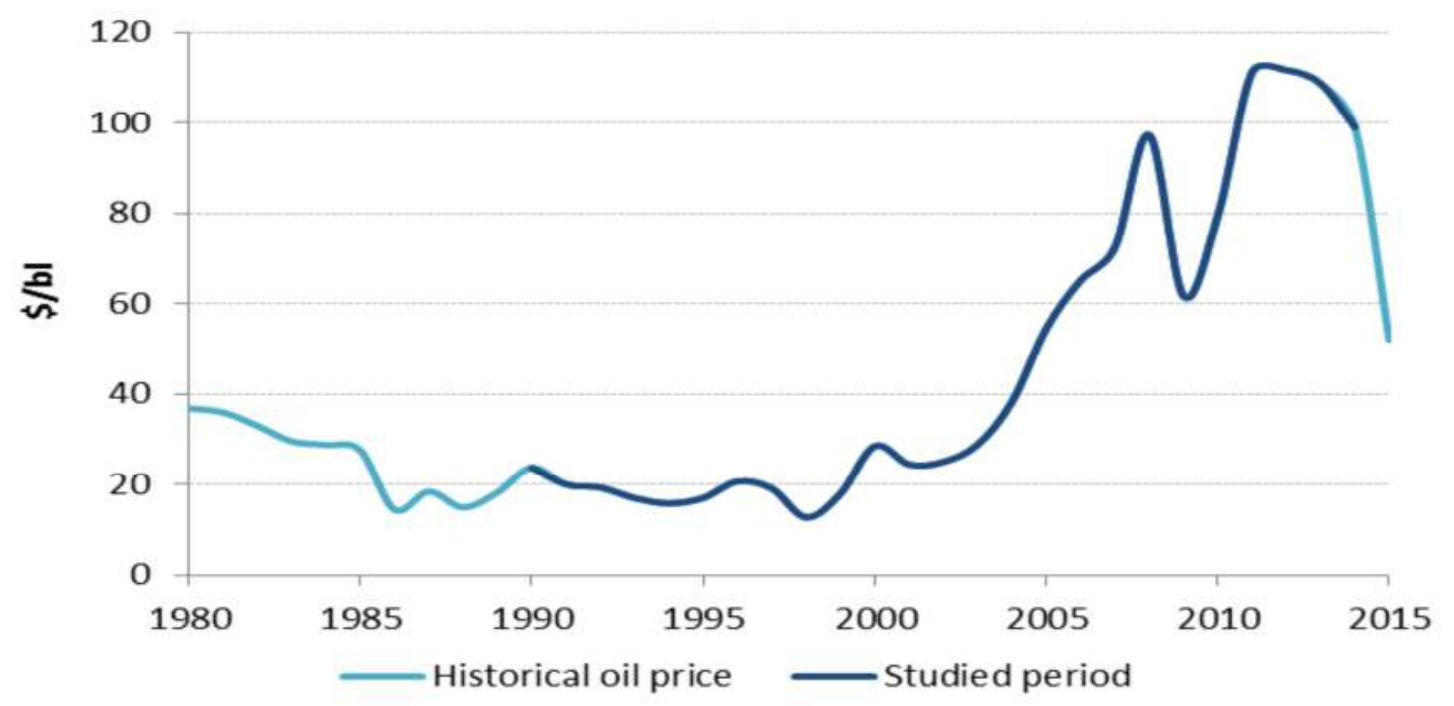

Figure 1. Historical Trends of Yearly Oil Price

Source: Adapted from BP (2015) and Energy Information Administration

Meanwhile, the persistence squeezing of the world market demand for oil by the developed economies like US, Canada etc. through inventions of hi-tech to reduce fuel consumable vehicle has further plunged oil multinationals into industrial crisis within the sub-Saharan African region which make it difficult for them to build necessary safety net for the host countries where they operate (Thomas Reuters, 2015). This evidence from the U.S retail market further shows that the aggregate demand has been altered to the extent that the overall world demand fall simultaneously, since the U.S market constitute part of the larger market for oil sales in the global market.

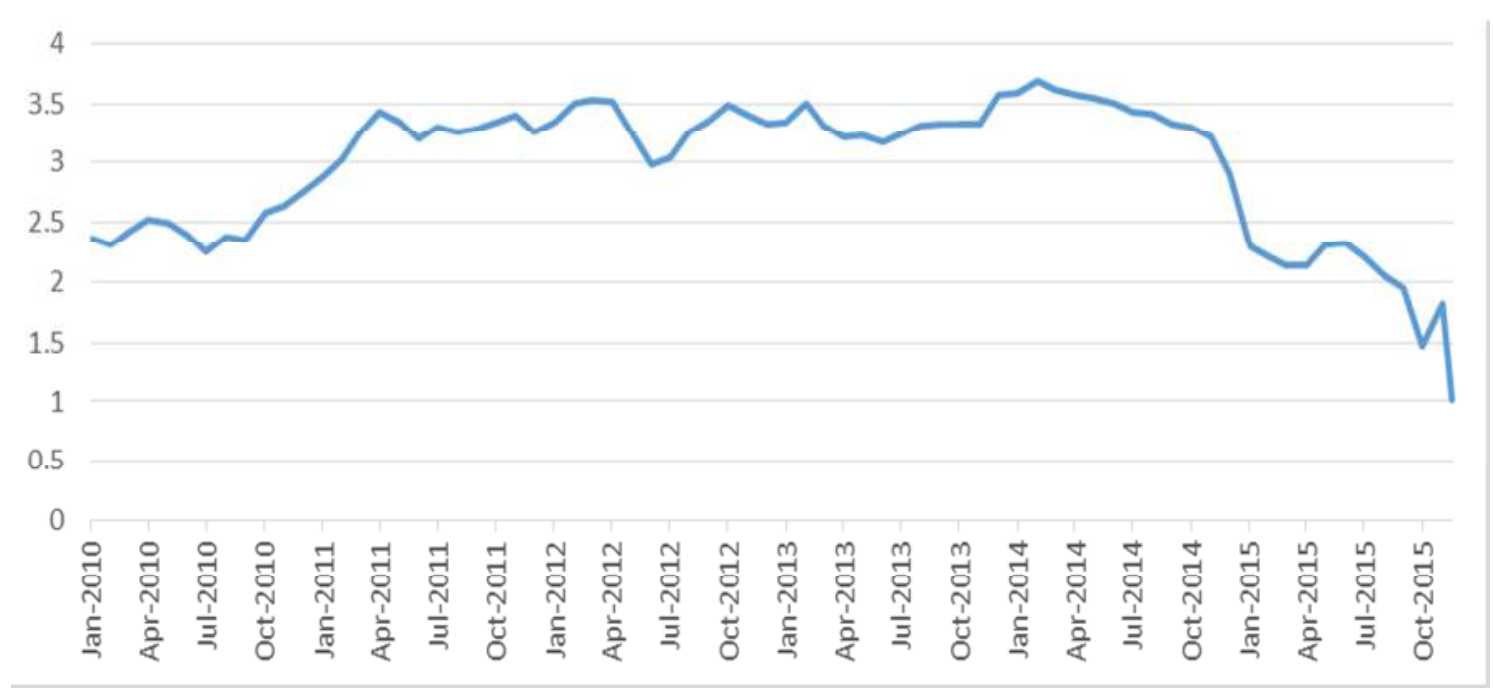

Figure 2. US oil sales by refiners (\$ per gallon)

Source: Adapted from U.S Energy Information Administration, 2016

That is, the invincible hands in the world market that dictates the market price had been altered by the U.S economy through her inventions in alternative source of 
energy like shale oil which in turn, had led to excess supply of crude oil in the world market and this could be traced as part of the remote cause of oil price collapse in recent years (Jhingan, 2005; Thomas Reuters, 2015).

It is therefore, pertinent to investigate the recent impact of oil price collapse on the Nigerian and Sudanese economies based on the recent continuous world price crisis that struck the oil market since past months. Angola, Nigeria and Sudan constitute three different small open economy that have no real impact on the world oil price but her economic growth performance largely determine by oil price collapse. Continual fall in oil price disrupts the individual economic growth of the selected sub-Sahara countries as a result of their large dependency on crude oil revenues, which has exposed them to economic instability in the past months (Africa's Pulse, 2015).

Consequently, the specific objective of this study, is to empirically investigate the nexus between oil price collapse and economic growth based on the fresh experiences from the selected countries (Angola, Nigeria and Sudan) on economic recession, oil exploitation and revenues, which have yet to be extensively explored. Therefore, this research intend to narrow the gap of Sub-Sahara African literature, especially those of Angola, Nigeria and Sudan between 2010 and 2015 using panel data sourced form World Bank data, CBN and CBS Statistical Bulletins. And this would be veritable tool to formulate economic policy in the near future.

This paper is therefore structured into five sections thus; the section one addresses the background and the objective of the study. Section two discusses the literature (conceptual and empirical works). Section three highlights the theoretical framework i.e. model specification for this study is done in this section. Meanwhile, the empirical analysis and discussion of the results are reveal in section four. While, section five comprises the recommendations and conclusion.

\section{LITERATURE REVIEW}

The literature on oil price collapse and immediate effects on the economic growth, particularly among the sub-Saharan oil producing economies are quite complex and it has been continuing to draw more concerns in recent times (Oriakhi \&Iyoha 2013). The historical prominent oil price hike of 1973 which was characterised by OPEC embargo on crude oil output brought about excess demand at the world market, had proved to be non-sustainable in the long run due the Islamic revolution that spread across Iran in 1979. And it was later escalated by cold war between Kuwait and Iran during same year. This rendered the OPEC regulation on output control less effective in terms of oil price stability (Pirog, 2004). Although evidently, oil price rose from $\$ 10$ per barrel to an unprecedented level of \$31 per barrel between 1998 and 2000. However, in 2001, it falls to \$18 per barrel before moving (rising) to over \$100 in 2013.

Oil price is define as the amount of monetary value attached to refine product from crude oil which is express in dollar exchange rate at the world market. This is to facilitate quick exchange rate among different countries during importations and exportations. The standard world oil price is differ from various domestic oil prices set by different home countries based on the value of their local currency, since it cannot be directly used to transact business at international fronts without being converted to dollar exchange rate. On this note, countries gains and losses from the current oil price woes varies across different economies, since their exchange rate in terms of dollar seem to be differ from one another, especially in sub-Saharan Africa where countries like Angola, Nigeria and Sudan slump to high exchange rate deficits with uncontrollable inflation rate at the domestic markets, which has made slightest fluctuation from the 
world market to disrupt the rate of economic across these countries growth paths in recent years.

It is pertinent to clearly explain the misconceptions that characterized the interpretations of different conceptual meanings in the word; oil shocks, oil price volatility and oil price collapse. Oil shocks (OPS) are the unprecedented rise or fall in price of oil at a particular period which does not stand the test of time i.e. it is too sudden within a short period of time. Oil price volatility (OPV) seems to be the regular deviance (swinging) of oil prices over a time while oil price collapse (OPC) said to be a special case of fall in price of oil commodity, where the price continue to drop permanently over time (Ebele, 2015).

Oil price collapse (OPC) is said to be the level of distortions that disrupt the smooth flow of goods and services between the demand and supply across the market, which requires active knowledge of efficient energy policy to reinstate stability (Hannan \& Bridwell, 2012).

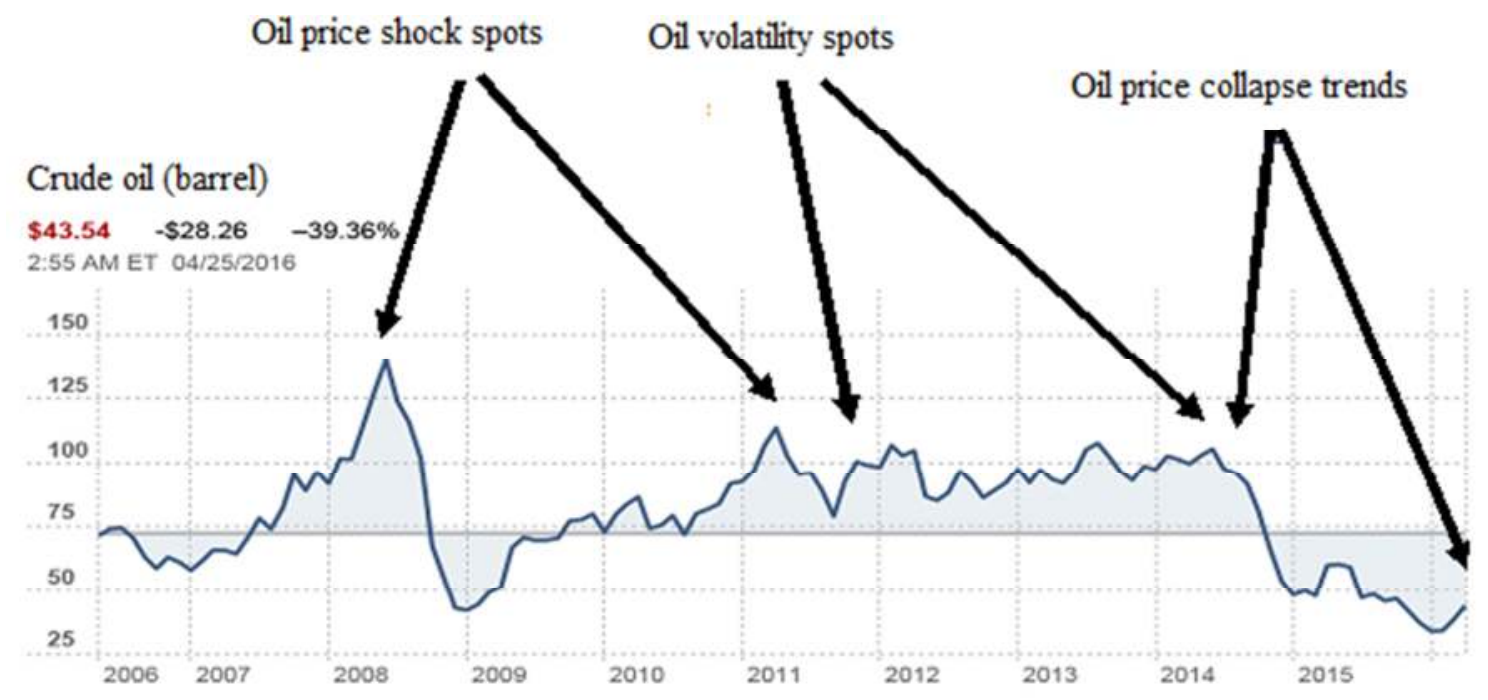

Figure 3. Crude oil price between 2006 and first quarter of 2016 (per barrel prices)

Source: Adapted from the Reuters, Thompson reuters, and Bloomberg, Februari, 2016

The above figure shows the trend of market balance within the global oil demand and supply between first quarter of 2013 and the projected third quarter of 2017 , it is interesting to note that there is sharp fall in the demand of crude from 93mmbpd in 1Q2014 to about 91mmbpd in 3Q2014, while the supply move in the opposite direction and since then it has sustained this. Although, it was projected by EIA that this market gap would significantly close in the 3Q2016. However, Panopoulou and Pantelidis (2016) opine that poor tools used in predicting (forecasting) the oil price in the previous years has led to the recent unexpected negative oil price that almost brought down real growth per capita in terms of gross domestic product across the globe. The authors argued that random walk models are less sophisticated and inappropriate when compare to regime-switching. The regime-switching models are statistically fit in respect to economic evaluation procedure for oil price projection (forecasts) after considering the deviations that may arise from different markets which are based on the fundamental value. 


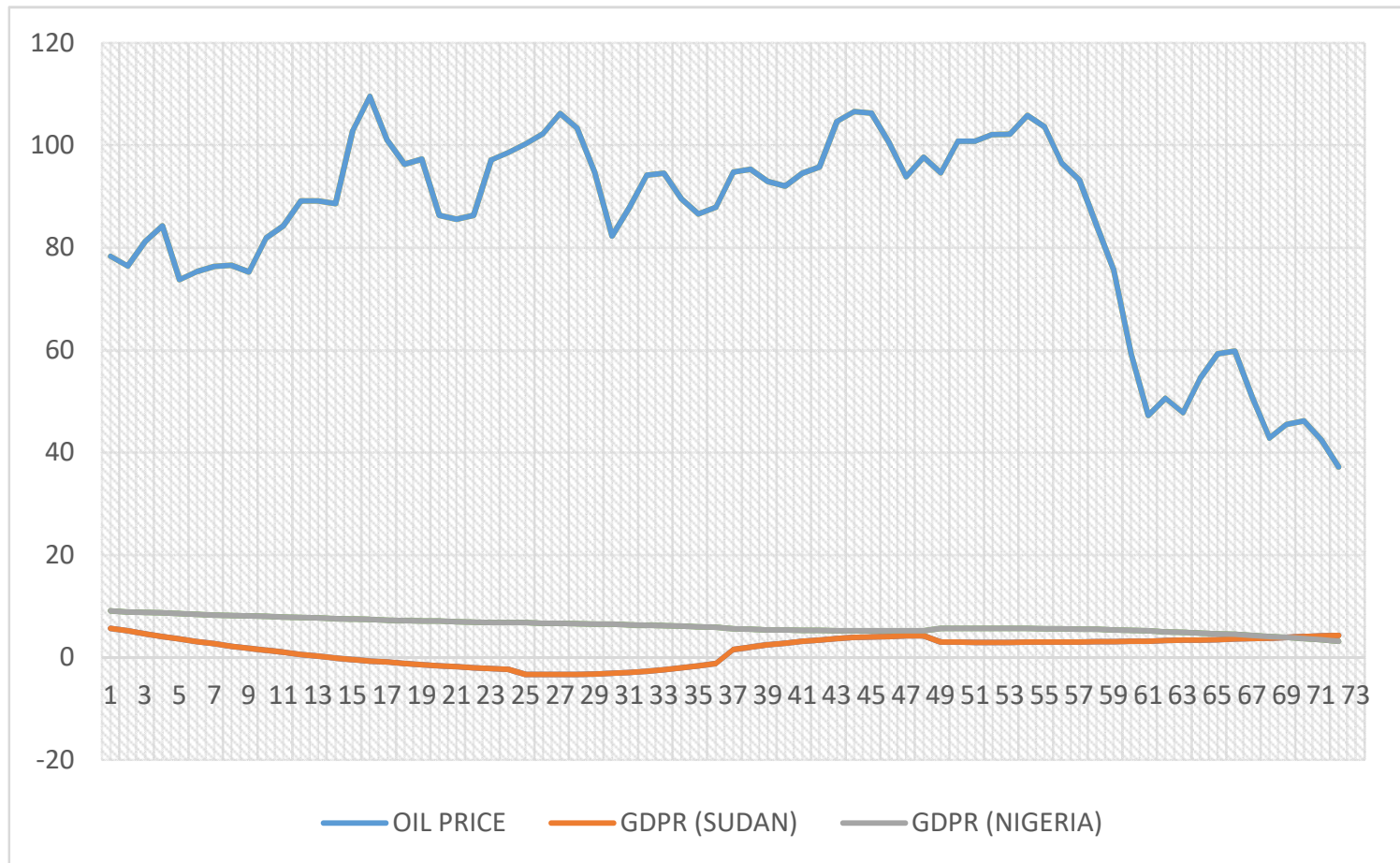

Figure 4. GDP (Growth rate) response to oil price collapse: Evidence from Nigerian and Sudan Source: data extracted from World Bank database (Author's computation).

Economic growth is the general increase in output level steadily over time. Economic growth is classified as the quantitative and sustainable rise in the nation's per capita output which is aided by simultaneous expansion in its consumption, trade volume, labour force, and capital (Jhingan, 2003). However, the driving factors of economic growth in Sub-Saharan Africa are not sustainable, especially factors from oil exporting nations such as Nigeria and Sudan. Exportation of crude oil has been one of the growth drivers in these economies and it has fall short to sustain the gains from windfall on their respective domestic economies in recent years.

Hamilton (1983) postulates that distortions in the price of oil affect the macroeconomic variables in an economy in terms of performance. In his findings, it was disclosed that fluctuation in oil prices cause prominent change in the size of the economic growth, using annual data from the US economy between 1949 and 1973. Schubert and Turnovsky (2011) argue differently through the adoption of endogenous growth model, in which they conclude that rise in energy prices has negative impact on the growth performance in the long run. On the other way round, Al-Awadi and Eltony (2001) posit that oil price has a substantial impact on the economic growth. Data were drawn from the Kuwaiti economy between 1984 and 1998, using both VAR and VECM to critically examine whether oil price fluctuations affect growth or not, where the estimated data indicates that there is association between the macroeconomics variables and the oil price indicator.

Ebaidalla (2014) empirically investigate the effect fluctuation in oil price on the growth of Sudanese economy between 1999Q4-2009Q4. The finding employed variance decomposition techniques and impulse response functions via unrestricted VAR, in which it was revealed that oil shocks significantly determine macroeconomic growth performance of the Sudanese economy, particularly the inflation and exchange rate indicators. In a related study by Samia (2011) posits that oil prices fluctuations in the international market have mixed blessings on the economic growth in Sudan. Using 
different data base experiment like bar chat, pie chat on data collated from World Bank and International monetary fund to access the challenges and opportunities on Sudanese economic development. He argues that over-reliance on oil has brought series of uncertainty to the growth path of the domestic economy such as unsustainable oil gains, Dutch Disease' and lack of incentives to drive diversification, especially in reference to recent instability of oil price at international front. Whereas, Oriakhi and Osazee (2013) conducted another findings on the Nigerian economy between 1970 and 2010, using the VAR approach, provides that oil price volatility impact on the real gross domestic product and other macroeconomic variable employed. This, also reveal that oil price influences economic growth indicator through the government expenditure, that is oil price changes dictates the government expenditure which in turn predicts economic growth in the long run.

Notably, Ebele (2015) argues that oil price fluctuations has negative impact on the growth of the Nigerian economy, using Engel-Granger co-integration method (technique). Whereas, Omojolaibi (2014) came up with different arguments, using structural VAR approach on the data collected between 1985 and 2010, in which he submitted that shocks due to oil price does not significantly have influence on the Nigerian growth but rather disruption from money supply. Although Almosharaf and Tian (2014) attributed the recent decline in economic growth of Sudan to two underlining factors: internal factors and external factors, using data drawn from Sudan central bureau of statistics in the last thirty years. They argue that internal factors such as excessive mono-economy (over-reliance on oil), weak government policy and separation of the south affect the economic growth process. While, external factors like US economic embargo on several occasions, external debt and global fall in oil price decline the Sudanese economic growth. However, Chuku et al (2011) and Asteriou \& Villamizar (2013) opine that dynamism in oil price could only distort economic growth in the short run while there no individual effect between the two variables in the long run.

In so far, it quite glaring that from virtually all previous empirical studies reviewed, none of these works principally concentrated on the effects of oil price collapse on the rate of economic growth from oil based economies, especially from Nigeria and Sudan . Interestingly, the scanty work done related to this research work, largely focus on volatility (fluctuation) and shocks in oil price on a single economy as a case study (e.g. Samia (2011), Oriakhi \& Osaze, 2013; Ebaidalla, 2014; Emmanuel, 2015; Moshiri, 2015; Uche et al., 2016)

\section{METHODOLOGY}

Standard growth theory (e.g. Solow) and energy theory i.e. price energy models are employed in the study with slim re-modification from the previous scholars e.g. Ayres (2013), Al-Khouri and Dhade (2014), Emmanuel (2015) and Khuran et al (2015) in order to analyse the original sources of growth with respect to oil price across the selected countries.

The energy growth model expressed output of $\mathrm{Y}$ as final stage of production and as a function of labour (L) capital (K) and energy (E) thus;

$$
\mathrm{Y}_{(t)}=\mathrm{F}\left[\mathrm{K}_{(t)} \mathrm{L}_{(t)} \mathrm{E}_{(t)}\right]
$$

Therefore the factor inputs of Labour, Capital, and Energy are employed to explain the independent determinants of economic growth (Y). 
In view of achieving the objective of this study, it is therefore pertinent to assess the growth rate with respect to its determinants thus;

$$
Y^{\wedge}(t)=\theta \lambda K^{\wedge}(t)+\theta \delta L^{\wedge}(t)+\theta \mu E^{\wedge}(t)
$$

Where the growth rates are denoted by the hats, $\theta$ s are used as weighting factors and subscripts transmitted to the inputs. Model (2) is well established in the body of literature to express relationship between growth inputs and output, i.e. energy growth (i.e. rise in oil price or revenue), capital formation and improved industrial output expect to grow output positively.

However, it is pertinent to inject other important determinant of growth with an outstanding modification so as to address the rate of distortions caused by the recent oil price collapse on macroeconomic variables performance of Nigeria and Sudan.

\section{Model specification}

$\mathrm{GDPR}=\mathrm{f}(\mathrm{EXR}, \mathrm{GCF}, \mathrm{OPR}, \mathrm{TOT})$

Where;

GDPR $=$ Gross Domestic Product in Growth rate

$\mathrm{EXR}=$ Exchange rate

$\mathrm{GCF}=$ Gross Capital Formation

$\mathrm{OPR}=$ Oil Price

TOT $=$ Terms of trade

Note: economic growth rate (GDPR) is used so as prevent spurious results, since $G D P R$ produces a more proven response to the regressors.

Model (2.1) is being transformed to (2.2) for the purpose of statistical computation thus:

$\mathrm{GDPR}=\alpha_{0}+\alpha_{1} \mathrm{EXR}+\alpha_{2} \mathrm{GCF}+\alpha_{3} \mathrm{OPR}+\alpha_{4} \mathrm{TOT}+\varepsilon_{\mathrm{i}}$

$\alpha_{0}=$ Intercept

$\alpha_{\mathrm{i}}=$ Coefficient of individual independent variable (where ${ }_{\mathrm{i}}={ }_{1}, 2,3,4,5$ )

$\varepsilon_{\mathrm{i}}=$ Stochastic error term

Panel data (random effects) analysis and Granger causality tests are used in the study. Why panel data analysis? According to Baltagi's arguments, panel data analysis takes heterogeneity into account, it allows less collinearity among variables, it also detects and captures effects that cannot be ordinarily observed by pure time series, and it helps to minimize bias error if individual variables are aggregated (Gujarati, 2013). Therefore, for the benefit of this study, panel models (e.g. random effects model) therefore reducing omitted variable bias and as well help us to establish the direction of causal effects between the variables of interest.

Transmission of fixed effects model to random effects model thus:

The fixed effects model permits each of the selected countries to have their individualspecific effects i.e. $\alpha$ i intercept which is time-invariant (fixed) and individual country possesses different intercept with similar slope parameters that does not vary over time. That is,

GDPR $i, t=\alpha i+\alpha_{1}$ EXR $i, t+\alpha_{2}$ GCF $i, t+\alpha_{3}$ OPR $i, t+\alpha_{4}$ TOT $i, t+\varepsilon i, t$

$i=1,2$.

$\mathrm{t}=1,2 \ldots, 72$.

Where $\mathrm{i}$ is ith country employed (cross-sectional observations) while $\mathrm{t}$ refer to time period of the variables employed (time series observations). 
Model 2.3 is transformed to model (2.4) i.e. error component model (ECM) and it is expressed thus;

GDPR $i, t=\beta i, t+\beta_{1}$ EXR $i, t+\beta_{2} \mathrm{GCF} i, t+\beta_{3} \mathrm{OPR} i, t+\beta_{4} \mathrm{TOT} i, t+\varepsilon i, t$

Interestingly, $\beta$ it is used to explain the individual country intercept instead of $\alpha i$ which is the case of FEM. The component of $\beta$ it can as well be specified thus;

$$
\beta i, t=\beta_{1}+\mathrm{v} i
$$

Where vi implies random error with zero mean and a constant variance $\sigma \mathrm{V}^{2}$ across country i.

Therefore, substituting 2.4 into 2.5, the model becomes;

GDPR $i, t=\beta i, t+\beta_{1} \mathrm{OPR} i, t+\beta_{2} \mathrm{IND} i, t+\beta_{3} \mathrm{INF} i, t+\beta_{4} \mathrm{TOT} i, t+\beta_{5} \mathrm{GCF} i, t+\mathrm{v} i+\varepsilon i, t$

GDPR $i, t=\beta i, t+\beta_{1} \mathrm{OPR} i, t+\beta_{2} \mathrm{IND} i, t+\beta_{3} \mathrm{INF} i, t+\beta_{4} \mathrm{TOT} i, t+\beta_{5} \mathrm{GCF} i, t+\mathrm{w} i$

Where, $\mathbf{w} i=\mathbf{v} i+\varepsilon i, t$

vi explains individual country-specific error component across country I (unobserved effects specific across cross-sectional country), while eit is the combination of crosssection error component and time series, i.e. cit means the idiosyncratic term due to it spread across country over time t. Here, it is assumed that both error components ( $v i$ and cit) are not correlated each other and as well not autocorrelated through both time series and cross-sectional units, that is;

$$
\begin{aligned}
& E(v i \varepsilon i t)=0 ; E(v i v j)=0(i \neq j) \\
& E(\text { citcis })=E(\varepsilon i j \varepsilon i j)=E(\varepsilon i t \varepsilon j s)=0(i \neq j ; t \neq s)
\end{aligned}
$$

Therefore $w i$ is not correlated with any of the regressor in the model.

To further estimate the extent at which the economies (i.e. Nigeria and Sudan) response to the recent oil price collapse at different period of time thus: According to Husain et al (2015).

$\ln (G D P \mathrm{Rnt} / \mathrm{GDPRSt})=\alpha+\beta * \ln ($ oil pricet $)+\gamma *$ time trendt.

Where:

$G D P \mathrm{R} t=$ ratio of GDP measure in growth rate $(G D P \mathrm{R} n t=$ Nigeria's GDPR, GDPRst= Sudan's GDPR)

Oil price $=$ Oil price at period $t$

$\beta \& \gamma=$ Express coefficients elasticity of the regressors

$\alpha=$ constant (shift) parameters

To establish the above arguments certain post estimation techniques are carried out in this study. Hausman test is conducted to test the most appropriate model in terms of consistency and efficiency to the study i.e. which model shows existence of correlation between component error term \& idiosyncratic term with any regressor specified in the model. While Breusch and Pagan Lagrange Multiplier Test is used to further verify whether the null hypothesis of no random effects model holds against OLS model, i.e. whether $\sigma_{u}{ }^{2}=0$. Under this, chi-square distribution is being followed with 1 degree of freedom (df), this is because single hypothesis that the variance of idiosyncratic term not different from zero $\left(\sigma_{u}^{2}=0\right)$ is being carried out.

The secondary data collected from the International Monetary Fund (IMF) data based (2015), World Bank data based (2015), World Development indicators (2015), U.S. Energy Information Administration (EIA), International Energy Agency (IEA), Worldwide Energy Statistics, index mundi, the global economy and trading economics data are used to estimate all the models specified above. 


\section{ESTIMATED RESULTS AND EMPIRICAL ANALYSIS}

This section discusses the empirical results estimated from the data collected thus:

$$
\begin{aligned}
& \text { GDPRt }=-9.6574-0.0809797 \mathrm{EXR} i, \mathrm{t}+7.81 \mathrm{e}-11 \mathrm{GCF} i, \mathrm{t}-0.02666 \mathrm{PR} i, \mathrm{t}+1.04 e-12 \mathrm{TOT} i, \mathrm{t}+0.368556 \mathrm{IND} i, \mathrm{t} \\
& \begin{array}{lllll}
(-1.35) & (1.43) & (2.33)^{* *} & (1.37) & (2.82)^{* * *}
\end{array}
\end{aligned}
$$

Note: Estimates in brackets represent the individual regressor t-statistics.

The results show that none of the regressor is statistically significant at any conventional level. Fixed effects model tend to be inconsistent and inefficient for the study due to time invariant of the intercept, with high level of correlation between the common shift parameters ( $\alpha \mathrm{i})$ and at least one of the independent variables (EXR,GCF, OPR, TOT, IND). It is therefore pertinent to employ random effect model in the study.

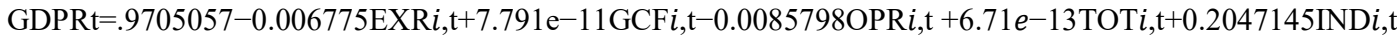

$$
\begin{aligned}
& \begin{array}{llllll}
(0.59) & (1.06) & (3.25)^{* * *} & (-0.54) & (1.80)^{*} & (4.80)^{* * *}
\end{array}
\end{aligned}
$$

Note: Estimates in brackets (parentheses) represent the individual regressor z-statistics, while the significantly estimated coefficients are explained with [***] [**] [*] as being significant at 1\%, 5\%, $10 \%$ level respectively.

It is observed from the random effect model (2.10) that industrial value and gross capital formation have significant impact on the rate of economic growth in Nigeria and Sudan. That is, one percent rise in oil price brings about 20 percent rise in economic growth of the selected countries, all things being equal. Though current exchange rate, oil price and terms of trade regressors seem not be significantly influence the rate of economic growth across the countries under review but oil price indicator with -0.009 reveal it negative effect on these economies, which fulfill the apriori expectation of this study. This is in connection with poor fiscal measures put in place by the individual apex financial institution of these countries. For example Nigeria's exchange rate rise significantly from \#160/ \$1 to \#480/ \$1 between 2010 and 2016 (it is worthy to note that this period serves as the scope of the study) which indicate over $100 \%$ increase.

The rho results that accounted for the percent of variation due to individual specific error term stood at 0 (i.e. there is no fraction of variance due Wi in model (2.7).

To empirically establish the justification of the model employed (random model) in the study. It is therefore pertinent to conduct some post estimation test e.g. Hausman test and Breusch and Pagan Lagrange Multiplier (LM) Test.

Hausman test results: $H=\left(\beta \mathrm{REM}-\beta_{\mathrm{fEM}}\right)^{\prime}\left(\mathrm{V}(\beta \mathrm{REM})-\mathrm{V}\left(\beta_{\mathrm{fEM}}\right)\right)\left(\beta \mathrm{REM}-\beta_{\mathrm{fEM}}\right)=9.15$

Where,

$$
\text { Prob }>\text { chi2 }=0.0274
$$

$\mathrm{H}=$ Hausman fe re model, $(\beta$ REM $-\beta$ fЕM $)=$ difference, ${ }^{\prime}\left(\mathrm{V}(\beta\right.$ REM $\left.)-\mathrm{V}\left(\beta_{\text {fEM }}\right)\right)=$ Variance co-variance matrix.

Table 1. Hausman's Test For Fixed and Random Effects Models

\begin{tabular}{llc}
\hline Regressors & $\boldsymbol{\beta} \mathbf{\text { fEM}}-\boldsymbol{\beta} \mathbf{R E M}$ & $\mathrm{V} \_\boldsymbol{\beta} \mathbf{\text { fEM}}-\mathrm{V} \_\beta \mathbf{R E M}$ \\
\hline EXR & 0.74 & 0.056 \\
GCF & $2.17 \mathrm{e}-13$ & $2.34 \mathrm{e}-11$ \\
OPR & 0.036 & 0.0123 \\
TOT & $3.67 \mathrm{e}-13$ & 0.00 \\
IND & 0.164 & 0.55 \\
\hline
\end{tabular}


Note: $\beta$ זEM $-\beta$ REM $=$ Differences between estimated coefficients from FEM and REM models. While $\mathrm{V} \beta$ ҒEM $-\mathrm{V} \_$REM= Square diagonal matrix.

Prob $>$ chi2 $=0.0274$, meaning that the Null hypothesis that random effects model (REM) is the most consistent and efficient for this study, which cannot be rejected.

$$
\begin{aligned}
& \text { Breusch and Pagan LM test results: GDPR (countrynum, t) }=6.53+1.13+0 \mathrm{t} \\
& \qquad \text { Chibar }^{2}=0.00, \quad \text { prob }>\text { chibar }^{2}=1.0000
\end{aligned}
$$

This study has found that oil price collapse has negative nexus with economic growth of Nigeria and Sudan, which support the early works of (e.g. Hamdi \& Sbia, 2013; Oriakhi \& Osazee, 2013; Ebaidalla, 2014; Kuboniwa, 2014 \& Ebele, 2015) that oil price has strong link with economic growth. This was achieved through random effects model (REM), and other post estimation tests such as Hausman and Breusch and Pagan Lagrange Multiplier Test which empirically establish the justification of the model employed (random model) in the study.

The empirical estimates reveal how it was difficult for the selected countries to adjust quickly to any form of external shock. The poor safety net put in place in terms fiscal measures among other measures contributed to the recent ugly trend i.e. economic recession witness in Nigeria during the period under review.

\section{CONCLUSIONS AND RECOMMENDATIONS}

\section{Conclusions}

In so far, empirical investigations have revealed the nexus between oil price collapse and economic growth from sub-Saharan Africa oil based economies, specifically from Angola, Nigeria and Sudan between January, 2010 and December, 2015, through panel random effects model (REM). The panel model showed that there is negative link between oil price collapse and the economic growth in the case of Angola, Nigeria and Sudan. Further empirical results from demand elasticity model reveal that coefficient estimate of oil price conform to the apriori expectation in accordance with theoretical (economic) intuition.

Interestingly, the other estimated regressors such as industrial output and gross capital formation are statistically significant, the key variable of interest, Oil price seem to be less significant but has negative nexus with the rate of economic growth due to oil price collapse, which further disclose that unprecedented oil price fall disrupts economic growth of the selected economies. In addition, this is connected with some other factors such as poor institutional quality, poor fiscal measure among others that further expose these economies to unprecedented external shocks which was characterized by skyrocket exchange rate that destabilize growth within the period under review.

\section{Recommendations}

In cause of the in-depth analysis, it has been discovered that poor institutional quality in the oil sector coupled with poor fiscal measure among others, further expose these economies to unprecedented external shocks that was characterized by skyrocket exchange rate, hence destabilize growth within the period under review. Therefore, the need for a robust fiscal measure is pertinent so as to sustain economic growth that is being achieved during oil revenues boom across the selected economies.

Proactive monetary policy should be put in place in order to curtail unprecedented inflation that could skyrocket domestic prices within the economies of 
the selected countries, as this would curb deficit exchange rate at the international fronts.

\section{REFERENCES}

Abubakar, A. M., Agayev, F., \& Ilkan, M. (2013) Energy demand interplay with real GDP and oil prices. Advances in Management \& Applied Economics, 3(4), 95103.

AfDB/OECD/UNDP (2015), African Economic Outlook 2015: Regional Development and Spatial Inclusion, OECD Publishing, Paris, http://dx.doi.org/10.1787/aeo2015-en.

Africa's Pulse (2015) An analysis of issues shaping Africa's economic future. Available online:http://www.worldbank.org/content/dam/Worldbank/document/Africa/Rep ort/Africas-Pulse-brochure_Vol11.pdf [Accessed 01/05/2016].

Akpan, E.O. (2009) Oil price shocks and nigeria's macro economy. In A Paper Presented at the Annual Conference of CSAE Conference, Economic Development in Africa, March 2009 (22-24).

Al-Khouri, R. \& Dhade, A. (2014) The role of savings in reducing the effect of oil Price volatility for sustainable economic Growth in oil Based economies: The case of GCC Countries. International Journal of Economics and Finance, 6(4), 172.

Apergis, N. \& Payne, J.E. (2014) The oil curse, institutional quality, and growth in MENA countries: Evidence from time-varying cointegration. Energy Economics, 46, 1-9.

Asteriou, D. \& Villamizar, D.D. (2013) The effects of oil price on macroeconomic variables in oil exporting and oil importing countries. International Journal of Energy, Environment and Economics, 21(4), 323-341.

Atalla, T., Joutz, F. \& Pierru, A. (2016) Does disagreement among oil price forecasters reflect volatility? Evidence from the ECB surveys. International Journal of Forecasting, 32(4), 1178-1192.

Ayres, R.U., Van den Bergh, J. M., Lindenberger, D., Warr, B. (2013) The underestimated contribution of energy to economic growth. Structural Change and Economic Dynamics, 27, 79-88.

Balcilar, M., Ozdemir, Z.A. \& Yetkiner, H. (2014) Are there really bubbles in oil prices? Physical: A Statistical Mechanics and its Applications, 416, 631-638.

Behmiri, N.B. \& Manso, J.R.P. (2013) How crude oil consumption impacts on economic growth of Sub-Saharan Africa? Energy, 54, 74.

Bentley, R. \& Bentley, Y. (2015) Explaining the price of oil 1971-2014: The need to use reliable data on oil discovery and to account for "mid-point" peak. Energy Policy, 86, 880-890.

Bildirici, M.E. \& Kayıkçı, F. (2013) Effects of oil production on economic growth in Eurasian countries: Panel ARDL approach. Energy, 49, 156-161.

Blomberg, S.B., Broussard, N.H. \& Hess, G.D. (2011) New wine in old wineskins? Growth, terrorism and the resource curse in sub-Saharan Africa. European Journal of Political Economy, 27, S50-S63.

Bretschger, L. (2015) Energy prices, growth, and the channels in between: Theory and evidence. Resource and Energy Economics, (39) 29-52.

Burbidge J., Harrison A. (1984) Testing for the effects of oil-price rises using Vector Autoregressions. International Economic Review, 25(2), 459-84.

Castro, C., Jerez, M. \& Barge-Gil, A. (2016) The deflationary effect of oil prices in the euro area. Energy Economics, 56, 389-397. 
Chuku, C.A., Akpan, U.F., Sam, N.R. \& Effiong, E.L. (2011) Oil price shocks and the dynamics of current account balances in Nigeria, OPEC Energy Review, 35(2), 119-139.

Cunado, J. \& Perez de Gracia, F. (2005) Oil prices, economic activity and inflation: evidence for some Asian countries. The Quarterly Review of Economics and Finance, 45(1), 65-83.

DE, O. \& Osaze, I.D. (2013) Oil price volatility and its consequences on the growth of the Nigerian economy: An Examination (1970-2010). Asian Economic and Financial Review, 3(5) 683.

Ebaidalla, E.M. (2014) The effects of oil price volatility on the Sudanese economy. Eastern Africa Social Science Research Review, 30(1), 1-26.

Ebele, E. (2015) Oil Price Volatility and Economic Growth in Nigeria: An Empirical Investigation. European Journal of Humanities and Social Sciences, 34(1), 1901-1918.

Ebohon, O.J. (1996) Energy, economic growth and causality in developing countries: A case study of Tanzania and Nigeria. Energy Policy, 24(5) 447-453.

Eltony, M.N. \& Al-Awadi, M. (2001) Oil price fluctuations and their impact on the macroeconomic variables of Kuwait: a case study using a VAR model. International Journal of Energy Research, 25(11) 939-959.

Fantazzini, D. (2016) The oil price crash in 2014/15: Was there a (negative) financial bubble? Energy Policy, 96, 383-396.

Ftiti, Z., Guesmi, K., Teulon, F. \& Chouachi, S. (2016) Relationship between crude oil prices and economic growth in selected OPEC countries. Journal of Applied Business Research, 32(1) 11.

García-Carranco, S.M., Bory-Reyes, J. \& Balankin, A.S. (2016) The crude oil price bubbling and universal scaling dynamics of price volatility. Physica A: Statistical Mechanics and its Applications, 452, 60-68.

Gil-Alana, L.A. et al. (2016) Time series analysis of persistence in crude oil price volatility across bull and bear regimes. Energy, 109, 29-37.

Gisser M., Goodwin T. (1986) Crude Oil and the Macroeconomy: Tests of Some Popular Notions. Journal of Money, Credit, and Banking 18, 95-103.

Hannan, B. \& Bridwell, L. (2012) Oil price volatility: How queuing theory can explain and warn of impending problems in our energy system. Pace University, 10 (2).

Hamilton, J. D. (1983) Oil and macro economy since World War II. Journal of political Economy, 91, 228-248.

Hamilton, J. D. (2003) What is an oil shock? Journal of Econometrics, 113, 363-398.

Hamilton, J.D. (2009) Causes and Consequences of the Oil Shock of 200708, Brookings Papers on Economic Activity, 2009(1), 215-261.

Hazarika, I. (2015) An analytical study on the impact of fluctuating oil prices on OPEC economies. International Journal of Trade, Economics and Finance, 6(3), 161164.

Herrera, A.M., Karaki, M.B. \& Rangaraju, S.K. (2016) Where do jobs go when oil prices drop? Energy Economics.

Hesary, F.T., Yoshino, N., Abdoli, G. \& Farzinvash, A. (2013) An estimation of the impact of oil shocks on crude oil exporting economies and their trade partners. Frontiers of Economics in China, 8(4), 571-591.

Hoeffler, A.E. (2002) The augmented Solow model and the African growth debate. Oxford Bulletin of Economics and Statistics, 64(2) 135-158. 
IMF (2015) Do resource windfalls improve the standard of living in Sub-Saharan African countries? Evidence from a panel of countries. Available online: https://www.imf.org/external/pubs/ft/wp/2015/wp1583.pdf 5/07/2016]

International Monetary Fund (2016) The impact of oil prices fluctuations on non-oil growth in Gabon, CEMAC: Selected Issues Paper, pages 4-8.

Investopedia (2015) Economic growth. Available online: https://index.investopedia.com/index/?q=Economic $\% 20$ growth $\& \mathrm{o}=40186 \& \mathrm{qo}=\mathrm{i}$ nvestopediaSiteSearch [Accessed 01/05/2016].

Jhingan M. L. (2003) Advanced economic theory: The theory of economic growth, $12^{\text {th }}$ edition. Delhi: Vrinda Publications (P) Ltd.

$\mathrm{Ju}, \mathrm{K}$. et al. (2014) Macroeconomic effects of oil price shocks in China: An empirical study based on Hilbert-Huang transform and event study. Applied Energy, 136, 1053-1066.

Katircioglu, S.T. et al. (2015) Oil price movements and macroeconomic performance: Evidence from twenty-six OECD countries. Renewable and Sustainable Energy Reviews, 44, 257-270.

Khuran, S., Liu, H., \& Rehana, N. (2015) Economic adjustment of United Kingdom and exchange rates. International Journal of Information, Business and Management, 7(2), 116-122.

Kindleberger, C.P. (1989) Manias, Panics and Crashes: A History of Financial Crises, second (revised) ed. Basic Books, New York.

Kirbyson, G. 2015, "Alberta feeling full brunt of oil price collapse", Bottom Line, $31(15), 1-1,5$.

Kuboniwa, M. (2014) A comparative analysis of the impact of oil prices on oil-rich emerging economies in the Pacific Rim. Journal of Comparative Economics, 42(2), 328-339.

Lescaroux, F. \& Mignon, V. (2009) On the influence of oil prices on economic activity and other macroeconomic and financial variables, OPEC Energy Review, 32(4), 343-380.

Menegaki, A.N. \& Tugcu, C.T. (2016) Rethinking the energy-growth nexus: Proposing an index of sustainable economic welfare for Sub-Saharan Africa. Energy Research \& Social Science, 17, 147-159.

Mijiyawa, A.G. (2013) Africa's Recent Economic Growth: What Are the Contributing Factors? African Development Review, 25(3), 289-302.

Mgbame, C. O., Donwa, P. A., Onyeokweni, O.V. (2015) Impact of oil price volatility on economic growth: Conceptual perspective. International Journal of Multidisciplinary Research and Development, 2(9), 80-85.

Moshiri, S. (2015) Asymmetric effects of oil price shocks in oil-exporting countries: the role of institutions, OPEC Energy Review, 39(2), 222-246.

National Bureau of Statistics (2015) Revenue generated in the Nigerian economy. Available online: http://www.nigerianstat.gov.ng/ [Accessed 01/05/2016].

Ndulu, B., \& O'Connell, S. (1999). Governance and Growth in Sub-Saharan Africa. The Journal of Economic Perspectives, 13(3), 41-66. Retrieved from http://www.jstor.org/stable/2646984

Ngongang, E. (2015) Financial Development and Economic Growth in Sub-Saharan Africa: A Dynamic Panel Data Analysis. European Journal of Sustainable Development, 4(2) 369-378. 
Nusair, S.A. (2016) The effects of oil price shocks on the economies of the Gulf Cooperation Council countries: Nonlinear analysis. Energy Policy, 91, 256-267.

Nwabughiogu, L (2016) Economy: Why rain is beating us now - Buhari. The Vanguard, 27 June Aonline]. Available at: http://www.vanguardngr.com/2016/06/economy-rain-beating-us-now-buhari [Accessed 28/06/2016].

Ogiri, I. H., Amadi, S. N., Uddin, M. M., \& Dubon, P. (2013) Oil price and stock market performance in Nigeria: An empirical analysis. American Journal of Social and Management Sciences, 4(1), $20-41$.

Olomola, P. A. \& Adejumo. A.V. (2006) Oil price shock and macroeconomic activities in Nigeria. International Research Journal of Finance and Economics, 3, 29-34.

Omojolaibi, J.A. \& Egwaikhide, F.O. (2014) Oil price volatility, fiscal policy and economic growth: a panel vector autoregressive (PVAR) analysis of some selected oil-exporting African countries. OPEC Energy Review, 38(2), 127-148.

Oriakhi, D. E., \&Osazee, I. D. (2013) Oil price volatility and its consequences on the growth of the Nigerian economy: An examination (1970-2010). Asian Economic and Financial Review, 3(5), 683-702.

Ozlale, U. \& Pekkurnaz, D. (2010) Oil prices and current account: a structural analysis for Turkish economy. Energy Policy Review, 38(8), 4489-4496.

Panopoulou, E. \& Pantelidis, T. (2015) Speculative behaviour and oil price predictability. Economic Modelling, 47, 128-136.

Pirog, R. (2004) Natural gas prices and market fundamentals. CRS Report for Congress Congressional.

Sachs, J. D. and A. Warner (1995a) Economic Reform and the Process of Global Integration. Brookings Papers on Economic Activity, 1, 1-95.

Santini D. (1985) The Energy-Squeeze Model: Energy Price Dynamics in U.S. Business Cycles. International Journal of Energy Systems 5, 18-25.

Schubert, S.F. \& Turnovsky, S.J. (2011) The impact of energy prices on growth and welfare in a developing open economy. Open Economies Review, 22(3), 365386.

Stern, D.I. (2016) Economic Growth and Energy. In Reference Module in Earth Systems and Environmental Sciences.

Tian, H. (2016) The Role of China's Real Economic Activity in Oil Price Fluctuations. Procedia - Social and Behavioral Sciences, 220, 522-530.

Tokic, D. (2015) The 2014 oil bust: Causes and consequences. Energy Policy, 85, pp.162-169.

Uche, N.C., Ijeoma, M. A., \& Uzoechina, B. I. (2016) Oil price volatility and macroeconomics performance in Nigeria: The principal-component GARCH approach. Journal Harmonized Research in Management. 2(1), 125-134.

U.S. Energy Information Administration (2013) Oil and Natural Gas in Sub-Saharan Africa. Independent Statistics \& Analysis, 1-25.

World BANK (2015) Economic Growth of Sub-saharan Africa. Available online: http://databank.worldbank.org/data/reports.aspx?source=2\&country=ARE\&serie $\mathrm{s}=$ \&period=http://data.worldbank.org/country/sub-saharan\%20africa [Accessed 24/04/2016].

Wu, G. \& Zhang, Y.-J. (2014) Does China factor matter? An econometric analysis of international crude oil prices. Energy Policy, 72, 78-86. 